\title{
PHYSICOCHEMICAL PRINCIPLES OF PHARMACY
}




\title{
PHYSICOCHEMICAL PRINCIPLES OF PHARMACY
}

\author{
A. T. FLORENCE
}

Department of Pharmaceutics,

University of Strathclyde

and

D. ATTWOOD

Department of Pharmacy, University of Manchester

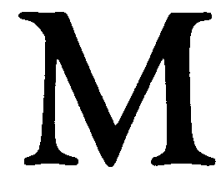


ISBN 978-0-333-44996-7

ISBN 978-1-349-19480-3 (eBook)

DOI 10.1007/978-1-349-19480-3

(c) A.T. Florence and D. Attwood 1981

Softcover reprint of the hardcover 1st edition 1981 978-0-333-44995-0

All rights reserved. No part of this publication may be reproduced or transmitted, in any form or by any means, without permission

First published 1981 by

THE MACMILLAN PRESS LTD

London and Basingstoke

Associated companies in Delhi Dublin

Hong Kong Johannesburg Lagos Melbourne

New York Singapore and Tokyo

ISBN 978-0-333-23404-4

ISBN 978-0-333-23405-1

The paperback edition of this book is sold subject to the condition that it shall not, by way of trade or otherwise, be lent, resold, hired out, or otherwise circulated without the publisher's prior consent in any form of binding or cover other than that in which it is published and without a similar condition including this condition being imposed on the subsequent purchaser 


\section{Contents}

Preface $\quad$ xi

1 Gases 1

1.1 Ideal and non-ideal gases 1

1.2 Application of the gas laws in aerosol formulation 3

$\begin{array}{ll}1.3 \text { Solubility of gases in liquids } & 6\end{array}$

$\begin{array}{lll}\text { 1.3.1 Effect of temperature on solubility } & 7\end{array}$

$\begin{array}{lll}\text { 1.3.2 Effect of pressure on solubility } & 7\end{array}$

1.3.3 Solubility of volatile anaesthetics in oil 8

1.3.4 Solubility of anaesthetic gases in blood and tissues $\quad 9$

2 Properties of the Solid State 13

Introduction

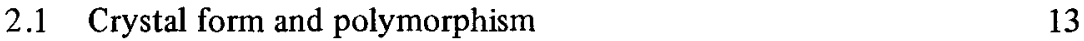

$\begin{array}{lll}2.2 & \text { Crystallisation and factors affecting crystal form } & 16\end{array}$

2.3 Analytical implications of polymorphism 18

$\begin{array}{lll}2.4 & \text { Thermomicroscopy } & 22\end{array}$

2.5 Relative stability of polymorphs and their bioavailability 22

$\begin{array}{ll}2.6 & \text { Dissolution of solid drugs } \\ 2.7 & 25\end{array}$

2.7 Biopharmaceutical importance of particle size 26

$\begin{array}{ll}2.8 \text { Wetting of powders } & 33\end{array}$

2.9 Solid solutions and eutectics 33

2.9.1 Eutectics and drug identification 36

$\begin{array}{ll}2.10 \text { Crystal growth in suspensions } & 37\end{array}$

2.11 Dissolution testing of solid dosage forms 38

3 Liquids 43

3.1 The liquid state 43

3.2 Cohesive forces in polar and non-polar liquids $\quad 45$

3.3 The structure of water 46

$\begin{array}{lll}\text { 3.3.1 Hydrophobic bonding } & 47\end{array}$

3.4 Properties of liquids $\quad 49$

$\begin{array}{lll}3.4 .1 & \text { Flow properties } & 49\end{array}$

$\begin{array}{ll}3.4 .2 & \text { Surface and interfacial tension }\end{array}$

3.4.3 Dielectric properties $\quad 54$

3.5 The liquid crystalline state $\quad 59$ 
vi Contents

4 Solutions

Introduction

$\begin{array}{lll}4.1 & \text { Concentration units } & 65\end{array}$

4.2 Thermodynamics - basic principles 66

4.2.1 Definitions 66

4.2.2 Laws of thermodynamics $\quad 67$

$\begin{array}{lll}4.2 .3 & \text { Free energy } & 73\end{array}$

4.2.4 Partial molar quantities - chemical potential 82

4.3 Thermodynamics of ideal and non-ideal solutions 84

4.3.1 Raoult's law $\quad 84$

4.3.2 Concepts of fugacity and activity $\quad 86$

4.3.3 Chemical potential in solution 93

$\begin{array}{lll}4.4 \text { Colligative properties } & 95\end{array}$

4.4.1 Vapour pressure lowering 95

4.4.2 Elevation of boiling point 96

4.4.3 Depression of freezing point 97

4.4.4 Osmotic pressure 98

4.5 Dynamic properties of electrolyte and non-electrolyte solutions 102

$\begin{array}{ll}\text { 4.5.1 Conductance of electrolyte solutions } & 102\end{array}$

$\begin{array}{lll}4.5 .2 & \text { Diffusion } & 106\end{array}$

$\begin{array}{lll}\text { 4.5.3 Viscosity } & 109\end{array}$

$\begin{array}{lll}4.6 & \text { Ionisation of drugs in solution } & 110\end{array}$

4.6.1 Dissociation of weak acids and bases and their salts $\quad 111$

4.6.2 The effect of $\mathrm{pH}$ on the ionisation of weakly acidic or basic drugs and their salts

$\begin{array}{ll}\text { 4.6.3 Amphoteric electrolytes } & 117\end{array}$

4.6.4 Ionisation of polyprotic drugs and microdissociation constants 118

$\begin{array}{lll}4.7 & \text { Buffer solutions } & 119\end{array}$

5 Solubility of Drugs in Liquids $\quad 125$

Introduction

5.1 Expressions of solubility 125

$\begin{array}{ll}5.2 & \text { Determination of solubility } \\ 5.3 & 126\end{array}$

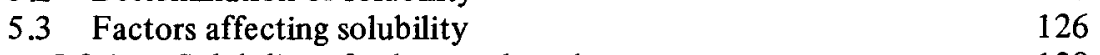

$\begin{array}{ll}\text { 5.3.1 Solubility of solutes in liquids } & 128\end{array}$

$\begin{array}{ll}\text { 5.3.2 Molecular surface area approach } & 129\end{array}$

$\begin{array}{lll}\text { 5.3.3 Structural features of simple molecules and aqueous } & \\ \text { solubility } & 130\end{array}$

$\begin{array}{ll}5.4 \text { Hydration and solvation } & 134\end{array}$

$\begin{array}{lll}\text { 5.4.1 Hydration of non-electrolytes } & 134\end{array}$

$\begin{array}{ll}\text { 5.4.2 Hydration of ionic species } & 135\end{array}$

$\begin{array}{ll}\text { 5.4.3 Hydrophobic hydration } & 135\end{array}$

5.5 The solubility of inorganic materials in water 136

$\begin{array}{lll}5.6 & \text { Solubility products } & 137\end{array}$ 
5.7 The effects of additives on solubility: the solubility coefficient 137

5.8 Influence of crystal size 139

5.9 Solubility of weak electrolytes 139

$\begin{array}{lll}5.9 .1 \quad \text { Acidic drugs } & 139\end{array}$

$\begin{array}{lll}5.9 .2 & \text { Basic drugs } & 140\end{array}$

5.9.3 Amphoteric drugs 141

5.10 Determination of solubility of organic electrolytes in aqueous solution

5.11 The solubility parameter 149

5.11.1 Solubility parameters and biological processes $\quad 150$

5.12 Drug solubility and biological activity 152

5.13 Solubility in mixed solvents

5.14 A recent formulation problem : Septrin infusion 154

5.15 The choice of drug salt 155

5.16 Partitioning phenomena 158

$\begin{array}{lll}5.16 .1 & \text { Extraction } & 160\end{array}$

5.16.2 Partitioning of weak electrolytes 162

5.17 Uses of $\log \mathrm{P} \quad 164$

6 Surface Chemistry 173

Introduction

6.1 Amphipathic compounds 173

6.2 The liquid-gas and liquid-liquid interface 174

6.2.1 Effects of amphiphiles on surface and interfacial tension 174

$\begin{array}{lll}\text { 6.2.2 Gibbs adsorption equation } & 175\end{array}$

6.2.3 Application of the Gibbs equation to surfactant solutions 177

$\begin{array}{lll}6.2 .4 & \text { Surface activity of drugs } & 179\end{array}$

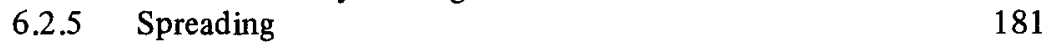

6.2.6 Insoluble monolayers 184

6.2.7 Pharmaceutical applications of surface film studies $\quad 188$

6.3 The solid-liquid interface 192

6.3.1 Contact angle and wettability of solid surfaces 192

6.3.2 Wettability of powders 193

6.3.3 Adsorption at the solid-liquid interface 196

6.4 Micellisation 205

6.5 Properties of some commonly used surfactants 213

6.5.1 Anionic surfactants 213

6.5.2 Cationic surfactants 213

6.5.3 Nonionic surfactants 214

6.6 Solubilisation 216

6.6.1 Determination of maximum additive concentration 216

$\begin{array}{ll}\text { 6.6.2 Location of solubilisate } & 217\end{array}$

6.6.3 Factors affecting solubilisation 218

6.6.4 Pharmaceutical applications of solubilisation 220 
7 Colloidal and Coarse Lyophobic Dispersions 223

Introduction

$\begin{array}{lll}7.1 & \text { Classification of colloidal systems } & 224\end{array}$

$\begin{array}{ll}7.2 \text { Colloid stability } & 224\end{array}$

$\begin{array}{lll}7.3 & \text { Emulsions } & 233\end{array}$

$\begin{array}{lll}\text { 7.3.1 Stability of emulsions } & 233\end{array}$

$\begin{array}{lll}7.3 .2 & \text { HLB system } & 234\end{array}$

$\begin{array}{lll}\text { 7.3.3 Multiple emulsions } & 238\end{array}$

$\begin{array}{lll}7.3 .4 & \text { Microemulsions } & 238\end{array}$

7.3.5 Biopharmaceutical aspects of emulsion systems 238

$\begin{array}{lll}\text { 7.3.6 Preservative availability in emulsified systems } & 241\end{array}$

$\begin{array}{ll}\text { 7.3.7 Mass transport in oil-water emulsions } & 242\end{array}$

$\begin{array}{ll}7.3 .8 & \text { Intravenous fat emulsions }\end{array}$

$\begin{array}{lll}7.4 & \text { Non-Newtonian flow } & 247\end{array}$

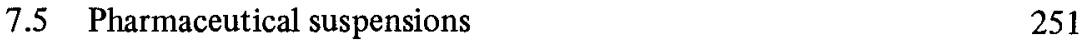

$\begin{array}{lll}7.5 .1 & \text { Settling of suspended particles } & 251\end{array}$

$\begin{array}{ll}7.5 .2 & \text { Suspension stability } \\ 7.5 .3 & 253\end{array}$

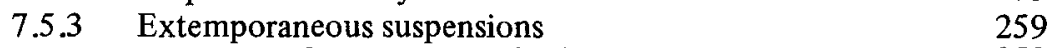

7.5.4 Rheology of suspensions of solid particles 259

7.5.5 Adhesion of suspension particles to containers 262

$\begin{array}{lll}7.5 .6 & \text { Crystal growth } & 265\end{array}$

7.6 Application of colloid theory to other systems 265

$\begin{array}{lll}7.6 .1 & \text { Cell-cell interactions } & 265\end{array}$

$\begin{array}{ll}\text { 7.6.2 Sorption of microbial cells on surfaces } & 267\end{array}$

$\begin{array}{ll}\text { 7.6.3 Blood as a colloidal system } & 269\end{array}$

$\begin{array}{ll}7.7 \text { Foams } & 271\end{array}$

$\begin{array}{ll}\text { 7.7.1 Foams: clinical considerations } & 272\end{array}$

$\begin{array}{ll}8 \text { Polymeric Systems } & 275\end{array}$

Introduction

$\begin{array}{lll}8.1 & \text { Water-soluble polymers } & 278\end{array}$

8.2 General properties of polymer solutions 279

$\begin{array}{ll}\text { 8.2.1 Polydispersity } & 279\end{array}$

$\begin{array}{lll}8.2 .2 & \text { Viscosity } & 281\end{array}$

$\begin{array}{ll}\text { 8.2.3 Gelling tendency } & 282\end{array}$

8.2.4 Heterogels 284

$\begin{array}{lll}8.2 .5 & \text { Syneresis } & 285\end{array}$

8.2.6 Macromolecular complexation 286

8.2.7 Binding of ions to macromolecules 288

8.2.8 Interaction of polymers with solvents including water $\quad 289$

$\begin{array}{ll}\text { 8.2.9 Adsorption of macromolecules } & 291\end{array}$

$\begin{array}{ll}\text { 8.2.10 Polymer crystallinity } & 293\end{array}$

8.3 Water-insoluble polymers and polymer membranes 293

$\begin{array}{lll}\text { 8.3.1 Permeability of polymers } & 293\end{array}$

$\begin{array}{lll}\text { 8.3.2 Ion-exchange resins } & 297\end{array}$ 
8.4 Details of specific polymers used in pharmacy and medicine 301

8.4.1 Carboxypolymethylene (carbomer, carbopol) 301

$\begin{array}{ll}\text { 8.4.2 Cellulose derivatives } & 302\end{array}$

8.4.3 Hyaluronic acid, agarose and carrageenan 304

$\begin{array}{ll}8.4 .4 & \text { Natural gums and mucilages } \\ 8.4 .5 & 305\end{array}$

$\begin{array}{lll}8.4 .5 & \text { Dextran } & 309\end{array}$

$\begin{array}{lll}8.4 .6 & \text { Polyvinylpyrrolidone } & 310\end{array}$

$\begin{array}{lll}\text { 8.4.7 Liquid polymers } & 312\end{array}$

8.5 Some applications of polymeric systems in drug delivery 313

$\begin{array}{lll}\text { 8.5.1 Release of drugs from matrices } & 315\end{array}$

$\begin{array}{ll}\text { 8.5.2 Microencapsulation } & 317\end{array}$

8.5.3 Rate-limiting membranes and devices 319

$\begin{array}{ll}8.6 \text { Mucus as a polymeric system } & 321\end{array}$

9 Principles of Drug Absorption and Routes of Administration 325

Introduction

9.1 Biological membranes and drug transport 325

9.2 Drug absorption from the gastro-intestinal tract 331

9.2.1 Structural principles of the gastro-intestinal tract 333

9.2.2 Permeability and the pH-partition hypothesis 334

9.2.3 Problems in the quantitative application of the pH-partition hypothesis 337

9.2.4 Bile salts and fat absorption pathways 342

9.2.5 Gastric emptying, motility and volume of contents 344

9.3 Absorption of drugs from intramuscular and subcutaneous
injections

$\begin{array}{lll}9.4 & \text { Topical preparations } & 354\end{array}$

9.4.1 Influence of drug 357

9.4.2 Influence of vehicle 361

9.4.3 Dilution of topical steroid preparations 366

9.4.4 Transdermal medication 366

9.5 Medication of the eye 368

$\begin{array}{lll}\text { 9.5.1 The eye } & 369\end{array}$

$\begin{array}{ll}\text { 9.5.2 Absorption of drugs } & 371\end{array}$

$\begin{array}{ll}\text { 9.5.3 Influence of formulations } & 372\end{array}$

$\begin{array}{lll}\text { 9.5.4 Systemic effects from eye-drops } & 377\end{array}$

9.6 Permeability of the oral mucosa; buccal absorption 377

9.6.1 Mechanism of absorption 378

$\begin{array}{lll}9.7 & \text { Inhalation therapy } & 379\end{array}$

9.7.1 Physical factors of deposition of aerosols 381

9.7.2 Experimental observations 383

9.7.3 Analysis of particle size distribution in aerosols 388

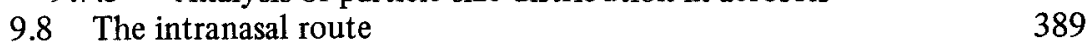

9.9 Rectal absorption of drugs 391 
10 Drug Interactions and Incompatibilities: a physicochemical viewpoint 401

Introduction

$10.1 \mathrm{pH}$ and other solvent effects $\quad 401$

10.2 Cation-anion interactions 404

10.3 Simple electrolytes and their effect on drug solutions 406

10.4 Complex formation 406

10.5 Other complexes $\quad 412$

10.6 Ion-exchange interactions $\quad 414$

10.7 Adsorption of drugs $\quad 415$

$10.8 \mathrm{pH}$ effects on drug behaviour in vivo $\quad 419$

10.9 Protein binding $\quad 425$

10.10 Interaction of drugs with $\beta$-cyclodextrin 433

Appendix 10.1: Drug interactions based on physical mechanisms 436

11 Chemical Stability of Drugs

Introduction

11.1 The chemical decomposition of drugs 445

11.1.1 Hydrolysis $\quad 445$

$\begin{array}{lll}11.1 .2 & \text { Oxidation } & 447\end{array}$

$\begin{array}{lll}11.1 .3 & \text { Isomerisation } & 449\end{array}$

11.1.4 Photochemical decomposition 451

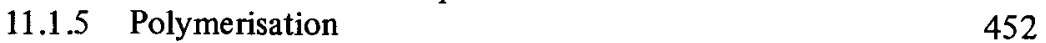

11.2 Kinetics of chemical decomposition in solution 453

11.2.1 Order of reaction $\quad 453$

11.2.2 Zero-order reactions $\quad 454$

11.2.3 First-order reactions $\quad 455$

$\begin{array}{lll}11.2 .4 & \text { Second-order reactions } & 457\end{array}$

11.2.5 Third-order reactions 458

11.2.6 Determination of order of reaction 459

11.2.7 Complex reactions 461

11.3 Kinetics of chemical decomposition in solid dosage forms 465

11.4 Factors affecting the rate of chemical decomposition 469

11.4.1 Liquid dosage forms 469

11.4.2 Semisolid dosage forms $\quad 479$

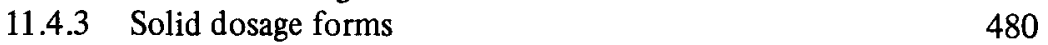

11.5 Stability testing of drugs 483

11.5.1 Effect of temperature on stability 484

11.5.2 Other factors affecting stability 491

Index $\quad 495$ 


\title{
Preface
}

This book sets out to provide the physicochemical background to the design and use of pharmaceutical products. It does not cover processing technology as such as this is dealt with adequately elsewhere. Rather an attempt is made to relate the physical chemistry of the drug or drug system to clinical usage. The book deals with the basic situations encountered in the progress of a drug from the dosage form to its site of action and how this can be controlled. Adhesion, deaggregation, solution, rates of solution, stability, diffusion, partition, aggregation, ionisation, interaction with water, and in teraction with other molecules are topics which have been tackled. The special problems of the various routes of administration of particular dosage forms are considered from a physicochemical viewpoint, bearing in mind the physiological constraints. Where relevant, the physical chemistry of adjuvant sutstances such as surface-active agents and polymers has been included as these substances are becoming more widely used to effect changes in the extent or duration of drug activity; often the basic mechanism of their effect is a physical and not a biological one.

Above all, however, an effort is made to unite the physical and biological aspects of pharmaceutics. Students sometimes forget that the same forces operate in inanimate and animate systems and early on in their training cannot see the relevance of the physical chemistry that is taught. It is hoped that this book will go some way towards bridging the gap between the fundamental and applied aspects of physical chemistry, pharmaceutical chemistry and biopharmaceutics. It does not purport to be a complete physical chemistry textbook, but should be useful as a textbook which follows on from the standard physical chemistry texts, for use in all years of the undergraduate course. As it is aimed at undergraduates the reference lists at the end of each chapter have been kept to a minimum size. It has frequently been difficult to decide which facts to reference and which not to, but we feel that our approach has been correct. We hope that the book will be of use to undergraduate students of pharmacy and other life sciences and to postgraduate students and practising pharmacists wishing to refresh their memories.

We would be pleased to hear from readers of any errors in our treatment of subjects. It has not been possible to acknowledge by citation of references the contribution of many pharmaceutical scientists who have made this book possible but we nevertheless would have found it impossible to write without recourse to the literature. This is, indeed, one of the reasons why we felt the book was necessary - undergraduate students in pharmacy have had to rely too much on seeking out facts in the original literature. Perhaps this book will ease the way somewhat.

\author{
A.T. Florence \\ Glasgow \\ D. Attwood \\ Manchester
}

